\title{
Astaire's Feet and Travolta's Pelvis: Maintaining the Boy Code
}

\section{Darcey CALlison}

Darcey Callison (callison@yorku.ca) is a choreographer known for his eclectic fusion of pure dance and theatrical invention. Critics have referred to him as a 'dance daredevil'. His current creative project, based on images of the nuclear family and consumerism, is titled "Revisiting the Sandbox" and will be presented at Buddies in Bad Times Theatre in December 2002. As a professor in the Department of Dance at York University he teaches a wide range of studio courses and lectures on dance. His research explores Authentic Movement as a base for training the expressive body, improvisation in early Western theatrical dance (Renaissance and Baroque), and representations of masculinity in Hollywood's male dancers.

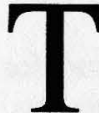

hrough cinematic images, text, and narratives, Hollywood films create and disseminate codes of behavior in North America and around the world. By examining the films Top Hat (1935, Sandrich) starring Fred Astaire and Saturday Night Fever (1977, Badham) with John Travolta, this paper explores the impact that these two actors' solo dancing roles had on reinforcing the expected ideals of masculinity in Western culture as comparative journeys from the dancing male as subject to object. Often Astaire's and Travolta's dancing appeared to occur spontaneously in social situations but, in fact, these dances were completely contrived, rehearsed endlessly, and edited specifically for a North American audience. By focusing on the dancing body of Fred Astaire as a representation of masculinity in 1935 and then contrasting it with the demonstration of maleness in the dancing body of John Travolta in 1977 , the evolution of the image of the cinematic male dancer I will discuss.

For well over two centuries female performers have dominated Western theatrical dancing. Only in the last century have women

torquere: Journal of the Canadian Lesbian and Gay Studies Association I Revue de la Société canadienne des études lesbiennes et gaies Vol. 3 (2001) @ CLGSA / SCELG 
choreographed and developed their own movement as a form of selfexpression. Dancing has primarily been an entertainment performed by women for the pleasure of men. This is particularly true of the early Broadway and Vaudeville shows that were the foundation of Hollywood's first musical entertainments, of which Astaire was a part.

Ted Shawn, an early modern dance pioneer, spent much of his career dancing with Ruth St. Denis on the Vaudeville circuit in the early 1900s. He also choreographed for such films as D.W. Griffith's Intolerance (1916). In his autobiography One Thousand and One Night Stands Shawn recalls telling one of his colleagues that he was thinking of becoming a dancer and was told that "men don't dance." Shawn reminded his colleague that men do, in fact, dance in other cultures, like in the Russian dances they had seen performed together. Shawn's colleague responded, "Oh those people, he dismissed them with a shrug. He admitted, though grudgingly, that dancing might be all right for aborigines and Russians, but he contended vehemently that it was hardly a suitable career for a red-blooded American male" (Shawn 11).

Within every culture there is one set of accepted behaviors for men and another for women. In North America all movements, gestures, reactions, and spacial relationships carry with them meanings that are learned and understood automatically as being correct behavior for men or for women. In Western culture if the expected image of maleness as active is challenged, the performer runs the risk of being seen as being different, objectified, and thus, shamed.

Objectification in dance occurs when a dancing body fulfills the viewer's fantasy, as either something to possess or as something that reflects the viewer's own ego. In her seminal article "Visual Pleasure and Narrative Cinema," Laura Mulvey defines these two objective viewpoints. Mulvey calls the first form of objectivation "active scopophilia," and defines it as the "pleasure in using another person as an object of sexual stimulation through sight" that happens because of the "separation of the erotic identity of the subject from the object on the screen" (271). Mulvey regards identifying with the image being viewed as the second category of objectification and describes this as the ego's identification "with the object on the screen through the spectator's fascination with and recognition of his like. Thus: The first (active scopophilia) is the function of sexual instincts, the 
second (identification) of ego libido" (271). The challenge of overcoming or subverting objectification while dancing is complex and arguably impossible. How does one dance for another's entertainment and not emphasize the separation between performer and audience that allows objectification to occur?

The fear of being seen as different, objectified, and shamed is one of the primary reasons why North American boys and young men choose not to dance. Instead, they choose other physical activities that fit with the social expectations of their masculinity, like contact sports such as soccer or hockey. William Pollack in his popular book Real Boys writes extensively about the fear boys and men have of being shamed and the lengths they will go to in order to fit in. He writes:

Perhaps the most traumatizing and dangerous injunction thrust on boys and men is the literal gender straightjacket that prohibits boys from feelings or urges seen (mistakenly) as 'feminine'... According to the ideal of 'no sissy stuff' such feeling and behaviors are taboo ... And when boys start to break under the strain ... they are usually greeted not with empathy but with ridicule, with taunts and threats that shame them for their failure to act and feel in stereotypically 'masculine' ways. And so boys become determined never to act that way again. (24)

Pollack refers to the gender straightjacket as part of the "boy code" inflicted on males in the West. The primary objective of the boy code is to assure the perception of man's heterosexuality through demonstrations that distinguish him as being different from females or homosexuals. Pollack writes that in his research throughout America he was "surprised to find that even in the most progressive schools and most politically correct communities in every part of the country and in families of all types, the boy code continues to affect the behavior of all of us - the boys themselves, their parents, their teachers, and society as a whole. None of us is immune - it is so ingrained" (6). Although Pollack points out other requirements of the boy code, the gender straitjacket and the shame of challenging it are the most pertinent to this study.

This paper maintains that the male dancer subverts objectification on the screen by successfully fulfilling the boy code requirements as understood in Western culture; by maintaining control over both the 
activity of dancing and the perception of that activity, the male dancer is able to sustain the subjective, active image expected of the socalled red-blooded American male.

The majority of both Astaire's and Travolta's dancing for films occurs in duet form and mostly as simulated courtship rituals with their female partners: literally, at times, sweeping the woman off her feet. Fred Astaire and Ginger Rogers are American dance icons, appearing together in ten films including Top Hat, Swing Time (1936, Stevens), and Shall We Dance? (1937, Sandrich). Astaire also danced with other starlets of the period, Rita Hayworth in You Were Never Lovelier (1942, Seiter) and Cyd Charisse Silk Stockings (1957, Mamoulian) among them. In the three successful films that featured John Travolta's dancing he was paired with Karen Gorney in Saturday Night Fever, Oliva Newton John in Grease (1978, Kleiser) and Debra Winger in Urban Cowboy (1980, Bridges). Only Grease is considered a musical; both Saturday Night Fever and Urban Cowboy are comingof-age soap operas. Travolta also made a sequel to Saturday Night Fever called Staying Alive (1983), written and directed by Sylvester Stallone. This picture was a box-office failure and the last picture to feature Travolta's dancing.

In many ways the duets performed by Astaire and by Travolta with their respective female costars demonstrate a preoccupation with the opposite sex and easily establish their character's heterosexuality. Maintaining the expected image of masculinity in the solo dance form proves to be trickier. Because the body, the site of the star's sexuality, is put on display in a solo dance performance, his gestures, his posture, his focus, and his use of space are open for interpretation and, more dangerously, misinterpretation. Focusing on Astaire's signature solo in Top Hat, and on the solo Travolta danced at the disco club in Saturday Night Fever, I will examine how each star maintained his masculine identity by using dance as a language to fulfill the boy code requirements even in an objectified feminine activity like solo dancing.

In his paper "Feminizing the Song and Dance Man" Steven Cohan argues that by making Astaire's talent as a dancer a spectacle that stops the show's narrative, the star's masculinity is feminized in the same way spectacle objectifies women by putting them on display (47). He goes on to point out that Astaire's masculinity comes through the complexity that binds the use of spectacle as a device for "to-be- 
looked-at-ness" as Mulvey defines it (Cohan 47). One way Astaire is able to maintain his masculine identity is by performing his danced sequences as elements of instruction, for his female costars, in his varied roles of teacher, director, lover, and, eventually, as himself, Fred Astaire, the patriarch, the dancer, the star. Cohan primarily focuses on Astaire's integrated musicals of the 50s and only occasionally refers to his early years in the $30 \mathrm{~s}$, when Astaire's male persona was first constructed and established in Hollywood.

In 1934 Fred Astaire and Ginger Rogers were given star billing for the first time in the film The Gay Divorcee (1934, Sandrich), which became a runaway box-office success. This was followed in 1935 with Top Hat, the first film that Astaire was credited with choreographing. In many ways Top Hat was a breakthrough film for Astaire. He was given some creative control and the film was critically applauded, receiving four Academy Award nominations including one for Best Picture. Regarded as one of Astaire's very best films, Top Hat was the first film to feature his solo dancing in a lavish production number as part of the film's primary entertainment. This dance number highlighted Astaire's talent as a dancer and helped to solidify his male image on the screen. All of his previous dance solos had been short spurts of virtuosity that occurred in living spaces not on performance stages, and had, up to that point, presented his character as the easy-go-lucky guy-about-town who could also, incidentally, tap up a storm. Astaire's Top Hat character, Jerry Travers, is a Broadway star appearing for the first time in London. About twenty minutes into the film he is in his dressing room preparing to dance an opening night sequence at the theater on a Broadway-type set. Just before his call time a telegram arrives telling him of the whereabouts of Ginger Rogers's character. As we hear the overture for his solo, he leaves his dressing room while arranging to have a plane made ready for him to fly off to join her.

When we first see the stage it is filled with three lines of men dressed in top hats and tails and carrying canes. They dance a short unison introduction moving from side to side and then parting down the middle to create a path for Astaire to walk down, like Moses parting the Red Sea. Astaire takes center stage to sing "Top Hat and Tails" while miming primping actions like putting in his shirt stubs and fixing his tie. Astaire's mimed gestures are an unmistakable part of the male dressing ritual, and identify him as the man-about-town 


\section{$60 /$ Callison}

readying himself for a night out, for adventure and action. The chorus of men emphasizes his lyrics with unison gestures or a few tap steps or beats with their canes. The chorus's movement is minimal and their faces are expressionless; it seems that they are afraid of showing any emotion for fear of expressing the wrong one. After watching the chorus several times, it seemed clear this lack of expression was a directorial instruction. A director's device that delivers the message that there is no emotion or physical bond between members of the chorus, and that their role is purely functional: they are there to support Astaire's star persona. Once the song ends, Astaire and the chorus walk in unison to one side of the stage stepping in time to the music and then emphasizing the melody with a few swaying changes of weight as they change direction and walk to the other side. They cross back again to center stage, turn and begin to walk upstage. Suddenly Astaire breaks into a short tapping sequence. The chorus faces him and responds in unison with their own sequence. Astaire tilts his head toward them as if listening and then answers them with an even more demanding sequence. The chorus admits defeat as they take three steps back and then leave the stage in symmetrical patterns. Pollack refers to the "cult of competition" as an accepted and expected characteristic in relationships between boys or young men: "the goal of winning at any cost, a quest for narcissistic glory at the expense of others" (273). The choreographed competitive motif sets Astaire apart from the chorus, demonstrates his supremacy as a dancer and justifies his dominance of the stage.

As the chorus exits, in defeat, on either side of the screen, Astaire is left alone to do what he does best: spectacular dancing. His solo is an inventive, playful mix of skill, timing, easy grace, and tapping virtuosity. About two minutes into the solo the stage lights dim and his body is almost silhouetted against a backdrop of a night sky. It seems that even Astaire's substantial dancing talent is not allowed more than a brief interlude of abstract expression before the choreography takes Astaire's body off display by giving him a recognizable activity. Now the choreography suggests a narrative of someone leaving a party and being followed home. Returning to the miming gestures first introduced during the song, Astaire mimes such events as shaking a hand, hearing something, casually walking away, suddenly turning to check something else, crouching low and tipping his top hat to say goodbye. The movement is interspersed with a few 
tap steps; he then turns suddenly and holds his body in complete stillness or anticipation, as if he were being followed. In this moment Astaire appears to be both the hunter and the hunted: a familiar image of man as the soldier, the fighter.

At this point the chorus reappears from the back and Astaire turns toward them, remaining low and still, like a creature ready for attack. Once the chorus stands silhouetted in a straight line across the back, Astaire uses his cane as a pretend gun, his tapping to create the sound of a gun going off, and proceeds to shoot each of the men in the line. Referred to as "the machine gun number" (Thomas 109), Astaire was able to execute a series of very difficult tapping riffs while subverting the audience's attention with an acceptable male activity: shooting the chorus. Once the last chorus member has fallen down, shot dead, the dance ends and Astaire is left alone to bow for his enthusiastic audience, now he is clearly the victorious hunter and master of his staged world. The camera reveals an audience made up entirely of men dressed exactly like Astaire and the dead chorus, in white ties and tails. In this closing image Astaire's overwhelming approval by men, who obviously share a bond with him as represented in their identical costumes, implies that his dancing is not only acceptable but also, perhaps, a desirable activity for a man.

In 1935 Astaire was still working to establish his Hollywood identity as a leading man. The choreographed sequence, the chorus, the song, Astaire's dancing and mime in Top Hat all contribute to solidifying the desired image of being overtly heterosexual, smart, aggressive, and, ultimately, dominant. For instance, Astaire's song "Top Hat and Tails" is about getting ready for a night out on the town, and suggests his male prowess and lust for adventure. Knowing he has just arranged for a plane to fly off to find Ginger Rogers, we can imagine what that adventure might be: sex. The chorus of men has the subliminal effect of saying that many men do, in fact, dance. The fact that the chorus remains mostly expressionless and dances very little may, in part, have been a solution to the problematic issue of seeing men dance with other men; an image that can easily be interpreted with homosexual connotations. It is not possible to know exactly what the filmmakers intended when they placed Astaire on stage with a chorus of men, but in 1935 the filmmakers certainly knew that dancing was dominated by female performers and that this fact would need to be addressed if Astaire was going to become the 
money-making star they wanted him to be. When highlighting Astaire's dancing for the first time in lavish cinematic production, it would be important to establish his heterosexuality and the impression that red-blooded American men dance. Astaire's interest in Ginger Rogers demonstrates his heterosexuality and the male chorus tells the audience that men do dance. Astaire's interaction with the chorus is almost adversarial. Initially he does not acknowledge the chorus and he never really dances with them; the most they do together is walk across the stage. When Astaire does burst into dance it is meant to be perceived as his challenge to others. The chorus responds by mimicking him. Astaire ups the ante and the chorus backs down and leaves defeated. The competition is over; the boys give up and Astaire, the winner, is left alone, victorious. Once it has been demonstrated that men do dance, and once Astaire is superior, the chorus exits and their dance imagery and choreographic potential is explored no further.

The chorus's return for the finale, to be shot down like ducks in a shooting gallery, is an image automatically associated with boys at play or men at war. This reminds us that under all the elegance and suave performance veneer Astaire is really just one of the guys. The approving male audience members assure us that Astaire's performance is acceptable. The fact that Astaire, the chorus, and the audience are mirror images of each other, dressed identically in top hats and tails, speaks to the conformity of Astaire and his performance. Astaire remains one of the guys, not only because the choreography says so, but also because the identical costumes say that all the men involved in this choreographed spectacle share a common bond: the boy code.

The virtuosity of Astaire's solo helps us see his dancing as a physical achievement: the trick or skill of being able to tap complex rhythms with his feet. The few times Astaire does acknowledge his audience is with an expression implying that what he just did was difficult, or a lot of fun. For the most part his smile seems pasted on and because he is an accomplished performer, we accept it. When the dancing becomes more difficult his smile disappears. Even through his easy grace it is possible to see that he is working at something that requires his full concentration. This effort is shown, in part, by his performance focus.

Choreographer and dancer Phyllis Lamhut uses the term "graining" to refer to the dancer's ability to focus inward on the body's 
kinesthetic experience. This is done, in part, by pretending to look inside at oneself and by not focusing directly on the stage space, audience, or a dancing partner. In this way a dancer can use his focus to draw attention to the inward kinetic of his dancing, like cutting into a fine piece of wood to reveal the beauty of the wood's grain. One of the effects of graining is to guide the viewer's attention to the task being performed and, in Astaire's case, our attention is drawn to his feet and their accomplished tapping. Graining is aided by the fact that the rest his body moves only minimally and when it does move either it takes a literal mimed shape or emphasizes the rhythms he is creating with his feet. If he were suddenly to start emphasizing movement of his torso in space, or to flow in indirect floor patterns across the stage it would have suggested something personal or abstract. This would open the door for the audience to question the meaning of his movement and leave his dancing open to personal interpretation and, most importantly, question. It is hard to imagine that Astaire would have had the same remarkable success he achieved as a popular tap dancer, if he had been a modern or ballet dancer, no matter how talented. His ability to grain and take the audience's focus toward the rhythmic activity he performed presented his dancing as the task of tapping; an accomplishment or a difficult feat. By presenting dance as a task Astaire followed a prescribed code that maintained the established values of the day and was, thus, easily accepted by a mass audience.

The accumulation of these choreographed events, movement choices, and the male symbolism of top hats, guns, and competition motifs results in our viewing Astaire's dancing as an example of the acceptable male attributes of virtuosity, humor, ingenuity, and glamor or spectacle as Steven Cohan writes in the above mentioned article on Astaire. These acceptable male attributes dominated Hollywood entertainment between the World Wars. The masculine qualities of virtuosity and ingenuity that the Hollywood musical of the 1930 s glamorized helped distinguish and distract America from the opposing forces of fascism and communism in Europe. America was more concerned with its own national economic and political problems. Hollywood counterbalanced these national fears by presenting American audiences with images of a strong America through its male identity, men who were capable, inventive, and, most importantly, unique. The choice to produce this first spectacle in 


\section{4 / Callison}

Astaire's career with both chorus and audience made up entirely of men highlighted Astaire's and America/Hollywood's adherence to the boy code: the male club that emphasizes the differences between American men and men of other nations or cultures; between men and women; between heterosexual and homosexual. Astaire's boycode persona in Top Hat exemplified the American ideal of the redblooded American male, idealistically bringing with him the suggestion of freedom from political concerns and abandonment to the carefree capitalist ideal of wealth and prosperity.

In the film Top Hat one does not objectify Astaire's body as if it were something to possess; instead one recalls the suave manners he achieves with such ease and the confidence he exudes. Fred Astaire is not the object of our desire. Instead, much like the approving male audience in the film, one longs for the ideals he represents. Such ideals include an adherence to the boy-code requirements and that Astaire reiterates with imagery, gestures, and relationships that fulfilled Western concepts of masculinity. This same adherence to the boy code requirements was also utilized by John Travolta in the 1977 film Saturday Night Fever, but with a very different outcome. John Travolta received an Academy Award nomination for his breakthrough role playing Tony Manero and was idolized by young American males who imitated him in the popular discos of the time. Travolta's performance is remembered now with nostalgic interest for all things 70 s, a campy archive of discomania. Most people I have asked find it difficult to remember much about the plot or characters of Saturday Night Fever. But one has only to strike the pose Travolta strikes on the movie poster (Travolta in a white suit, left arm raised in the air with his finger pointing up, and his pelvis tilted back ready for action) to recall that Travolta's dancing was and is the film's enduring attraction. Watching the 1977 film Saturday Night Fever, we do notice Travolta's great body, and we lust after the character not his social circumstance, which is exactly what the filmmakers wanted and expected.

Saturday Night Fever could have been a 1970s version of a Rebel Without a Cause, (1955, Ray) were it not that Tony does have a cause: dancing. This working-class Joe is a great dancer and it is the one thing he can do that gives him the sense of purpose and satisfaction he has not found in the rest of his life. In this film, dancing works as a transformational vehicle through which Tony is able to see his life 
more clearly. In turn, the audience is able to empathize with Tony, his need to fulfill his role in his community, and his desire to free himself from the dull predictability of his life. By 1977 the Woman's Movement and Gay Liberation were established and both questioned the traditional roles that men and women fulfilled in society. In the late 70s audiences recognized - and some even empathized with the strain Tony was under in maintaining a 'traditional' masculine identity.

In her book Gender Trouble, Judith Butler points out the problem of viewing male or female characteristics as the inevitable consequence of the body. Sexual identity, she argues, is fluid and complex and characteristics of maleness or femaleness are learned and performed "normative ideals rather than a descriptive feature of experience" (23). In Saturday Night Fever we can see that Tony has learned to play his role successfully and that his dancing is a means of reaching outside his learned behavior of tough, working-class, straight guy to something that gives him a feeling of freedom, something that he longs for. But he is stuck with a job at the hardware store and a girlfriend whose need to please him is oppressive. When he finally meets a female partner who dances with a talent equal to his, he begins to see that the role he performs with his family, friends, and girlfriends may not be the one he would choose if he were truly free to make a choice.

It follows that if sexual identity is a learned normative practice then expression outside this norm has the potential for being seen as different and thus shamed by society. In Tony's macho environment, solo show dancing could easily have caused him shame. Yet Tony is free to dance with the female partners he chooses at the disco without being questioned. Travolta's masculine image is set up throughout the film, but when his dance solo draws near, the film goes out of its way to assure the Western audience that he is a red-blooded American male. The film emphasizes that he is a heterosexual and a popular male stud on the prowl. This nearly neurotic overstatement begins when Travolta and his friends enter the disco.

About half way into the film Travolta takes his older brother, who has just rejected the priesthood, to a disco with his friends. As they enter the disco we see a nearly nude woman go-go dancer on a platform, letting us know immediately that we are in heterosexual bar. Once the camera has left this dancer she is never seen again in 
the film, not even in the background. As I combed through the rest of the scene I was unable to fathom where this woman would have danced. It seems as if she was edited in later, perhaps as an afterthought.

The guys enter. They are familiar and popular. Women approach them and they are all ready to party. Travolta's need to fight off the attention he receives from the women in the disco informs us of how successful he is at fulfilling his masculine role, and his obvious popularity creates a context that most young heterosexual men would find desirable, even fantastical. Travolta and his gang sit down at a table and a woman comes over and asks Travolta to dance. He accepts but reminds his brother that this woman is not his usual partner. While dancing, Tony and the woman engage in some verbal sparring that is meant to be amusing, but is misogynist. The woman lets Travolta know she is interested in him and that she is sexually available. However the boy code requires that the male remain dominant and Travolta's verbal abuse and rejection of this sexually 'liberated' woman shows us that his character is really the one in control. This woman and her so-called liberation are not a threat to his macho image and his adherence to the boy code. Put in the context of the Women's Movement in 1977, the subtext of this interaction is very revealing of the difficulties men and women experienced in the late 70 s when new values of social codes were busy throwing into question their established sex roles.

It is also obvious that this woman is not a great dancer and we think Travolta is going to walk away frustrated, but then he turns around and walks past this woman, ignoring her, and crosses the floor with the confidence of a thoroughbred stallion. Leading with his pelvis, and spiraling his chest from one side to the other, he swaggers through the crowd on the dance floor, taking up more personal space than would be allowed if the moment had not been choreographed.

The camera cuts to the table of his male friends (reminiscent of the male audience in Astaire's film) who pause, notice him, and recognize that he is about to break loose and dance. Then it cuts back to an empty dance floor. All the other dancers have moved to the sides: like in Astaire's entrance in Top Hat, Moses has parted the Red Sea. Now Travolta faces the audience and takes a couple of steps forward, stops, and makes an asymmetrical shape with his whole body, left arm and leg turned in, right arm extended to the side. Then 
he quickly does a catch step to the backside and walks forward again turning his gesture leg to exaggerate the movement of his pelvis thus emphasizing the location of his male prowess. At the same time he makes quick and casual gestures with his forearms similar to a hitchhiker thumbing for a ride: these gestures begin near his body and travel outward toward the sides and emphasize the rhythmic movement of his pelvis. At this point Travolta's body posture resembles that of other Hollywood male icons, such as John Wayne or James Cagney, and like them Travolta's torso is held and exposed with little or no movement: creating a shield that tells us he is in control and that keeps others at a distance. Crowds on both sides of the screen frame the picture and cheer Travolta on with clapping and shouting, "Yeah, right on." He stops center front, keeps the pulse of the music with his body and looks from side to side and mimes checking his cufflinks, left then right: similar to Astaire's mime and primping in Top Hat and with the same effect of identifying a man getting ready for action. Next Travolta places his hands on his belt buckle and pulls his pants up slightly, advertising the location of his penetrating potential, and then does shoulder rolls as he bends his legs into a deep parallel plié. At the bottom there is a short pause, he shifts his pelvis to the side and does a sequential movement up his body into a pointing shape. The camera cuts low to angle up, giving him a powerful towering appearance and showing his upper torso and arm pointing and scanning across the screen: both the angle of this shot and the long stable shape suggest his ability to stay firmly in control. He turns to profile as the camera cuts front again to show his whole body. This time he makes quick circles with and around his forearms while keeping time with his feet (touch step, touch step) and leading with his pelvis, moves to the side of the dance floor. He turns to place his body on a slight diagonal, bends his knees a little to allow his pelvis to move easily as he rocks it forward and back to the beat of the music. By advertising his pelvis in this cross over and pose he invites the audience to view his body and to imagine his sexual potential.

This opening sequence and everything in Travolta's disco solo is danced to a four four beat creating a very predictable choreography, but the point of Travolta's dancing is neither the artistry of the choreography nor the inventiveness of the movement, as it is in Astaire's solo in Top Hat. Travolta's solo dance in Saturday Night 
Fever is part of a character study of a young working class ItalianAmerican male; choreographed and edited specifically to demonstrate the character's male confidence. Within this sequence, the setup and choreography never lets the audience forget that he is a macho heterosexual.

Travolta begins his solo in reaction to the 'liberated' woman who initially asked him to dance, she was immediately shown to be both sexually aggressive and an inept dancer. His frustration with her makes his solo a kind of rivalry, or declaration that establishes his dominance. This behavior is acceptable behavior for boys and demonstrates what Pollack refers to as "the imperative men and boys feel to achieve status, power, and dominance" (24). Throughout Travolta's dancing solo the rejected woman stands isolated from the rest of the crowd on the upper stage right corner of the disco floor. She leans on one leg and appears to be simultaneously rejected and waiting for him to finish, watching him like the others. Travolta's character does not acknowledge her and at the end of his solo she simply disappears much like the naked go-go dancer that set up this sequence. The scenario suggests the presence of the always-available female, highlighting the difference between her passivity and his activity, the woman as potential prize to the conquering male.

When Travolta's character takes center stage, he moves without apology; the crowd's approval of him lets us know this male's dancing is acceptable. His movement is simple: arm, hand, leg, and pelvic gestures strung together. Because the human torso easily reveals both emotional content and abstract objectification, Travolta - like Astaire - moves his torso minimally. As Travolta's solo progresses he occasionally smiles at the crowd, but the show of pleasure is always in response to the crowd's reaction: in much the same way that Astaire acknowledges the audience in his solo from Top Hat. These facial responses are not an indication of any pleasure that Astaire or Travolta might be feeling from their dancing, which could easily come dangerously close to an emotional response and leave their dancing open to interpretation. In both films Astaire's and Travolta's solos are manipulated so the audience knows exactly what to look at and what to think. When the stars respond with their faces they are simply acknowledging their audience's response and agreeing that they are, indeed, fabulous dancers.

The accumulation of this filmed sequence and Travolta's dance 
performance maintains the unspoken requirements of the boy code in Hollywood cinema of the 70s. His dancing is the task of showing off, much like Astaire's tapping virtuosity, with no suggestion of personal expression. Travolta is in control of his dancing, his body, the admiring women, and the crowd of men and women who obviously love his dancing. Travolta's suggested sexuality invites attention to the gestures he makes with his body, or, at the very least, lets us know it is OK to watch him. The fact that in the film both men and woman, all presumably heterosexuals, are cheering him on, fulfills Mulvey's definition of both "active scopophilia" (sexual stimulation through sight) and "identification with ones like" (271).

Travolta's invitation to us to pay particular attention to his bodily gestures is similar to the graining focus used by Astaire to draw our attention to his feet. However, while Astaire's focus remains indirect, Travolta's focus is direct. Travolta knows what we are looking at; he wants us to look at him and to imagine his sexual potential as demonstrated through his dancing. This aggressive objectification of Travolta's body was the highlight of Saturday Night Fever. What is significant in Travolta's case is that he actively invites the audience to look at his body and the suggestive gestures he performs, and so participates actively in his own objectification, which becomes the driving action of the scene. This subversively fulfills the figurative gender straightjacket that Pollack defines as an essential boy code requirement: "As soon as a boy behaves in a way that is not considered manly, that falls outside the Boy code, he is likely to meet resistance from society - he may merely be stared at or whispered about, he may be humiliated, he may even get a punch in the gut, or he may just feel terribly ashamed" (58). Travolta's active objectification allowed him to participate in what is considered a feminine activity, without experiencing the consequences or shame that can easily come with such behavior.

In contrast to 1935 , by 1977 the new social issues of the day dictated that Travolta's character needed to perform demonstrations of his masculinity for fear of being misread by an American audience, which was busy dealing with the changing times caused by the Feminist and Gay Movements of the late 60s and 70s. To the earlytwenty-first-century American eye Travolta is by far a more masculine dancer. By contrast, Astaire, to the contemporary eye, seems fay with his limp wrist, slim body, and easy-going manners. In 1935 
Astaire's masculinity did not have to be demonstrated in the same way Travolta's needed to in 1977 , when a limp wrist would have given his character homosexual connotations and damaged his constructed heterosexual identity. Astaire's aggressive interest in Ginger Rogers was enough to establish his sexual preference for he and Hollywood needed the audience to perceive and agree with the notion that dancing was an acceptable career for a red-blooded American male. By emphasizing the boy-code attributes of virtuosity and ingenuity, and by choreographing stereotypical male activities such as grooming for a night on the town, competing with the male chorus, and shooting a gun, Astaire demonstrated that his dancing is a masculine activity. In 1977 Travolta's manufactured masculinity is clearly the objective of his dancing in Saturday Night Fever. He actively uses his performance as a demonstration of his male prowess, making a clear plug for the staying power of the straight male in a rapidly changing world.

The culture-carving power of the Hollywood machine manufactured and commercially exploited the carefully constructed images of the dancing male that perpetrated rather than threatened the established codes for masculine identity in the above mentioned films. Other Hollywood examples of this include Gene Kelly in Anchors Aweigh (1945, Sidney), Kevin Bacon in Footloose (1984, Ross), or Patrick Swayze in Dirty Dancing (1987, Ardolino). Also recent independent films, even with their politically correct homosexual subplots, such as The Full Monty (1997, Cattaneo) and Billy Elliot (2000, Daldry), can be included in the list of nonthreatening male dancers.

In order to assist his discussion of the gender clichés being challenged in Western Theatrical dance, Arnd Weseman, in the introductory editorial of Ballet International's issue Dance and Gender, quotes Judith Butler: "There is no reason to divide the human body into male and female sex, unless this division meets the economic needs of heterosexuality and bestows on heterosexuality a naturalist luster, the luster of man / woman cliché which stresses differences instead of common ground" (i). Such words equally apply to my own discussion of dance and male gender. By stressing gender difference and emphasizing acceptable male attributes, Astaire's and Travolta's heterosexual luster was never in question. Their work clearly served the economic needs of the stars themselves and of the 
Hollywood machines that manufactured their films. Also, the resulting cultural spinoffs, such as an increased interest in social dancing lessons, generated an ancillary financial market within the culture for which the films were created.

Learning to dance like Fred Astaire has been one of the main promotional slogans for many ballroom studios, from the mid $30 \mathrm{~s}-$ when Astaire's films were first released - to today. Imitation of Fred Astaire and John Travolta is one way the boy code continues to be learned and performed by boys and young men across North America and beyond: one of the results of the global distribution of Hollywood films. Top Hat and Saturday Night Fever function both as entertainment and as social conformist propaganda. When Pollack writes that the boy code "is so ingrained" that "no one is immune" he can rightly include the images, the impact, and the influence of Hollywood's male dancers (6).

\section{Final Thoughts}

In the early 1960s, while growing up in the small rural town of Dawson Creek, British Columbia, I took my first dance lessons with a woman named Mrs. White. At the end of each school year Mrs. White put together a recital for parents and friends. Being the only boy in a group of about thirty girls, I was dubbed Mrs. White's Fred Astaire. I think this was mostly because it helped to justify my participation in her classes. I was allowed to perform certain dances, such as the Highland Fling or the Mexican Hat dance, but other dances, such as the Can-Can, I did not perform. Of course I was allowed to tap. Eventually the strain, and shame, of continuing classes with Mrs. White was too great, both for her and for me, and I stopped attending. It was not until many years later that I started to dance again, and many years after that, I began to realize what had happened and what I had given up. Fred Astaire had given me some means of access to dance as a boy, but not enough.

The widely distributed world of Hollywood films has done nothing to challenge the Western cultural norms of masculinity and dance. Hollywood's use of dancing to maintain the boy code is both a reflection of and an instruction for societal norms. Hollywood's portrayals make it nearly impossible for boys and young men to pursue a passion for movement that expresses something beyond the functionality of maintaining these boy code requirements. Even 
young men's current fascination with Hip-Hop, which finds its roots in the exuberant acrobatics of Breakdancing, has simply upped the ante of extreme inventiveness, sharing more with the innovations of Astaire's tapping and with Travolta's active objectification than with any need to make statements that are personal, emotional, or that might be open for other interpretations. Hollywood has yet to provide us with images of male dancers that are emotional, expressive, delicate, or vulnerable.

In my ten years of teaching dance in a university Dance Department only a handful of young men have been enrolled. Professional studios in local and metropolitan communities share this same lack of young men's presence. Although the singular boys and young men who do dance in these studios and universities feel it is where they want to be, even that they belong, the pressure to maintain the boy code often shames them into quitting.

Fortunately, contemporary choreographers, such as Mark Morris and Lloyd Newson, are creating works for the stage that challenge the boy code and its many requirements. In 1989 Morris created and danced the title role of queen Dido in his seminal choreography Dido and Aeneas. Considered to be a big man, particularly in the dance world, Morris inhabited his character without the aid of 'female' costuming or extreme makeup. Morris used his almost fully unadorned male body to represent a female character and by doing so freed himself from the "imaginary construction" that Judith Butler argues is "the culturally instituted fantasy" imposed on each of us because of the body parts we are born with (90). In 1996 Lloyd Newson used the interior of an English pub as a setting to explore the male psyche in his work Enter Achilles, a dance that explores the lonely, and at times violent, insecurities that come with the pressure of fulfilling the boy code requirements. The catalyst in Newson's all male work is a stranger who enters the pub and interferes with the noisy surroundings by selecting soft music on a jukebox and dancing casually by himself. Once the pub's male regulars notice the stranger and his activity, they isolate him and mock him. When they physically attack, the stranger protects himself by turning quickly on the spot, and shedding his business suit to reveal a Superman costume. The attack takes on a comical tone as the pub gang lifts the stranger over their heads and make him soar through the air as if he were an airplane. As this scenario progresses, two men leave the group and begin to 
explore, in secret, a physical relationship with soft gestures that turn into a gentle giving of their body's weight, to each other. As these two images contrast and interact with each other simultaneously on stage the complex laws of the boy code are revealed as a coverup symbolized by the Superman costume - for the lack of intimacy or meaningful contact in the lives of the men in the pub.

Newson ends his sixty-minute exploration of violence and vulnerability with a poignant image that speaks to the difficulty, and perhaps impossibility, of ever finding a way out of the boy code's labyrinth of demands. One man from the gang is left crying over the rape and mutilation of his plastic life-size female sex doll while the stranger sings "the Impossible Dream."

Morris's and Newson's challenging productions, which have both been filmed, do not have the wide distribution available to Hollywood films. However, both productions have toured successfully as live performances, and the cinematic versions have been presented on television and in select film festivals. They are a long way from the Hollywood stamp of approval, but a promising start at showing alternate views of the male body as an emotional, vulnerable, and expressive instrument.

Fred Astaire and John Travolta's dancing performances were constructed to tell us that red-blooded American men dance, at least in the fantastical world of the cinema. However, they do not tell us how to overcome the real-world stigma attached to dancing that keeps boys and young men away from their passion in universally large numbers. If Mrs. White or I had any idea why we were uncomfortable with each other, I wonder if we could have changed our behavior. In all honesty, I doubt it. After all, Mrs. White and I were not reacting to our own experiences in the studio, but to our fears of other people's perception of my dancing. In the end, like Fred Astaire and John Travolta, maintaining the boy code was the priority, one that we both had to accept.

Thanks to Anna Blewchamp, Selma Odom, and Lisa Cochrane for their valuable assistance.

\section{Works Cited}

Ardolino, Emile, dir. Dirty Dancing. With Patrick Swayze and 
Jennifer Grey. Vestron, 1987.

Badham, John, dir. Saturday Night Fever. With John Travolta and Karen Lynn Gorney. Paramount, 1977.

Bridges, James, dir. Urban Cowboy. With John Travolt and Debra

Winger. Paramount, 1980.

Butler, Judith. Gender Trouble. New York: Routledge, 1999.

Cattaneo, Peter, dir. The Full Monty. With Robert Carlyle, Mark Addy, and William Snape. Fox Searchlight, 1997.

Cohan, Steven. "Feminizing the Song and Dance Man: Fred Astaire and the Spectacle of Masculinity in the Hollywood Musical." Screening the Male: Exploring Masculinities in Hollywood Cinema. Ed. Steven Cohan and Ina Rae Hark. New York: Routledge, 1993. 46-69.

Daldry, Stephen, dir. Billy Elliot. With Julia Walters and Jamie Bell. Universal Studios, 2000.

Griffith, D[avid] W[ark], dir. Intolerance. Image, 1916

Kleiser, Randal, dir. Grease. With. John Travolta, Oliva NewtonJohn, and Stockard Channing. Paramount, 1978.

Lamhut, Phyllis. Summer Dance Intensive. Simon Fraser University: Burnaby, B.C. Summer 1979.

Mamoulian, Rouben, dir. Silk Stockings. With Fred Astaire and Cyd Charisse. MGM, 1957.

Morris, Mark, perf. and chor. Dido and Aeneas. Dir. Barbara Willis Sweete. Rombus, 1989.

Mulvey, Laura. "Visual Pleasure and Narrative Cinema." The Routledge Reader in Gender and Performance. Ed. Lizbeth Goodman and Jane de Gay. New York: Routledge, 1998. 27075.

Newson, Lloyd, chor. Enter Achilles. Dir. Clara Van Gool. DV8 / BBC / RM Arts, 1996.

Pollack, William. Real Boys. New York: Holt, 1998.

Ray, Nicholas, dir. Rebel Without a Cause. Warner, 1955.

Ross, Herbert, dir. Footloose. With Keven Bacon, John Lithgow, and Dianne Wiest. Paramount, 1984.

Sandrich, Mark, dir. The Gay Divorcee. With Ferd Astaire and Ginger Rogers. RKO, 1934.

—. Shall We Dance? With Fred Astaire and Ginger Rogers. RKO, 1937.

—. Top Hat. Perf. Fred Astaire, Ginger Rogers RKO, 1935. 
Seiter, William A., dir. You Were Never Lovelier. With Fred Astaire and Rita Hayworth. Columbia, 1942.

Shawn, Ted. One Thousand and One Night Stands. New York: Da Capo,1979.

Sidney, George, dir. Anchors Aweigh. With Gene Kelly and Frank Sinatra. MGM, 1945.

Stallone, Sylvester, dir. Staying Alive. With John Travolta and Cynthia Rhodes. Paramount, 1983.

Stevens, George, dir. Swing Time. With Fred Astaire and Ginger Rogers. RKO, 1936.

Thomas, Bob. Astaire: The Man, The Dancer. New York: St. Martin's Press, 1984.

Wesemann, Arnd. "Introduction." Ballet International/Aktuell Tanz. 8-9 (August 1998): i. 